\title{
CAMPOS DE IMAGENS LITERÁRIAS EM LÍLIA A. PEREIRA DA SILVA:
}

\section{Poesia-desenho-pintura}

\author{
FIELDS OF LITERARY IMAGES IN LÍLIA A. PEREIRA DA SILVA: \\ Poetry-drawer-painter
}

\begin{abstract}
Antonio Donizeti da CRUZ ${ }^{109}$
RESUMO: Lília A. Pereira da Silva é escritora, poeta, pintora, desenhista, musicista e ilustradora de livros. Tem publicados 103 livros nas áreas de Literatura: poesia, romance, literatura infantil, Artes plásticas (pintura, desenho), Didáticos de Direito e de Psicologia. Lília nasceu em Itapira (SP). Desenvolve uma técnica que vai desde o acrílico, esmalte, óleo, purpurina, colagem, tela, alumínio, papéis diversos, aquarela, ao guache. Na obra de Lília A. Pereira da Silva, as imagens poéticas ocorrem entrelaçadas no universo imaginário, que registra imagens-desenhos-pinturas alicerçadas nos registros-chave, que direcionam para um elaborado processo poéticocriativo centrado na imaginação poética e na ARTE. Suas obras vão do figurativo ao abstracionismo, apresentando também ousadas técnicas expressionistas e surrealistas, com uma obra que revela manifestações e dramas humanos.
\end{abstract}

PALAVRAS-CHAVE: Imaginário; Projeto estético; Poesia; Pintura; Desenho; Lília A. Pereira da Silva.

ABSTRACT: Lilia A. Pereira da Silva is a writer, poet, painter, drawer, musician and illustrator of books. She has published 103 books in Literature areas such as: poetry, novel, infant literature, plastic Arts (painting, writing), Didactic books of Law and Psychology. Lília was born in Itapira (SP). She has developed a technique that uses acrylic, glaze, oil, bronze powder, collage, aluminun, several papers, aquarelle and watercolour. In Lília A. Pereira da Silva's work the poetic images occurred interlinked in the imaginary universe, which registers images-drawings-paintings based in key-registers that lead to a poetic-creative elaborated process, centered on the poetic imagination and Art. Her works contemplates from the figurative to abstractionism and also presents audacious expressionist and surrealist techniques in a work that reveals human manifestations and dramas.

KEYWORDS: Imaginary: Esthetic project; Poetry; Painting; Drawing; Lília A. Pereira da Silva.

109 Professor Associado da Universidade do Oeste do Paraná (UNIOESTE), campus de Marechal Candido Rondon, e Bolsista Produtividade em Pesquisa pela FUNDAÇÃO ARAUCÁRIA - Paraná. 


\section{Lília A. Pereira da Silva: a Artista da palavra e das cores}

A arte está em minha alma como pássaro vibrando tão quase sempre cantando. Lília A. Pereira da Silva

Lília A. Pereira da Silva é escritora, poeta, pintora, desenhista, musicista e ilustradora de livros. Tem publicados 103 livros nas áreas de Literatura: poesia, romance, literatura infantil, Artes plásticas (pintura, desenho), Didáticos de Direito e de Psicologia. Lília nasceu em Itapira (SP). Reside em Itapira, SP. Foi professora de pintura e de piano, tendo participado de concertos. Cursou Secretariado, Jornalismo, Direito e Psicologia. Foi traduzida duas vezes em Paris, em Roma e em Barcelona. A poeta Lília tem poesias versadas em dezenas de outros países. Possui vasta correspondência internacional. Foi a primeira oradora feminina no Salão Nobre da Faculdade de Direito do Largo de São Francisco, em 1971. Representou o Brasil em Literatura, em Toluca, México (1972), e em Artes Plásticas, em Santiago no Chile (1974). Pertence a inúmeras antologias no Brasil e no exterior e é detentora de incontáveis prêmios artísticos, inclusive no México (DF), em Battipaglia e Roma (Itália, Paris e inúmeros nacionais). Instituiu um prêmio anual, desde 1995, de Poesia e Desenho, com apoio da Prefeitura Municipal, Câmara Municipal de Esportes, Cultura e Turismo de Itapira, SP.

Alguns dos títulos publicados pela Autora: 33 anos de Poesia - 2 vol. (1991), Diário na Suiça (2005); Chuva de gatos verdes (2004); Europeanas (1997); Saia de cigana entre galáxias (2001), Desenho e Pintura (2002), Carnaval Brasil (1996), Mínimos Conceitos (poesias) e Contos Abstratos (1994), entre outros livros que abrangem a área da poesia, romance, histórias infantis, direito, teatro, psicologia, etc. Lília tem recebido crítica favorável à sua obra de poetas, críticos, artistas plásticos, brasileiros e internacionais. Sobre a Poeta-artista, Cecília Meireles afirma: "Lília - a de olhos guardados nas rosas..." (MEIRELES apud SILVA, 33 anos de poesia, vol. II).

Ilustradora de livros nacionais e estrangeiros, Lília A. Pereira da Silva é também autora de 500 Poesias sem Fronteiras, totalizando cinco volumes de traduções de cinquenta países. Em 1998 publicou o livro intitulado The Angles's Surprise, com suas 
poesias versadas em oito línguas, tais como inglês, francês, espanhol, italiano, japonês, latim, norueguês e alemão.

Desenhista e pintora, Lília realizou quase 300 mostras. Recebeu um grande número de prêmios brasileiros e estrangeiros: Battipaglia, Itália; México, DF; Roma; Paris; entre outros. Tem participado também de inúmeras antologias no Brasil e exterior. Pertence a várias Associações e Academias: "União Brasileira de Escritores" (UBE SP), “Amici Linguarum" (Alemanha), "Societé Académique des Arts Libéraux" (Paris), e outras. Foi professora de pintura e piano, tendo participado de concertos. Em relação às artes plásticas, suas obras encontram-se em museus brasileiros e estrangeiros (USA, México, Holanda, França, Itália, Mônaco, Chile.) Desenvolve uma técnica que vai desde o acrílico, esmalte, óleo, purpurina, colagem, tela, alumínio, papéis diversos, aquarela, ao guache (entre outros materiais). Suas obras vão do figurativo ao abstracionismo, apresentando também ousadas técnicas expressionistas e surrealistas, com uma obra que revela manifestações e dramas humanos.

Na obra de Lília A. Pereira da Silva, poesia, desenho, pintura e imaginário estão entrelaçados e apresentam uma confluência de textos-imagens que evidenciam a correlação de sentidos da arte. No dizer da Artista Lília,

\footnotetext{
Não se prefere uma arte, ela é que nos escolhe. Minha primeira manifestação artística foi no campo da poesia, depois do desenho e em seguida da música. As artes são irmãs. Todas são mensagens do transbordamento de sensibilidade dos que nasceram para transmiti-las. Para mim acontece que a poesia, a pintura e a música se fundem num trabalho literário, pictórico e musical. Quantas vezes não ouço uma música ouvindo-lhe a poesia, sentindo-lhe as cores? Outras, olho uma tela e sou envolvida pela sua música, pelas sua poesia. Em certos momentos, leio versos e até mim vêm as suas cores, as suas melodias. (SILVA, 2002. Contracapa).
}

Consoante as afirmações de Lília, a poesia, o desenho, pintura e imaginário, são potências capazes de dar sentido à vida. Ao buscar a essência da linguagem, a Artista Lília realiza o poder mágico através das palavras, das formas e cores: ser mediação, comunicação, exercício de construção de sentidos.

Conforme Jean Cohen, a poesia é "uma exaltação do mundo, uma celebração das coisas, devolvidas pela consciência totalizante ao seu poder emocional e imaginário" (1987, p. 250-251). Para o autor, a poesia é uma segunda potência da linguagem. Ela tem um poder de magia e de encantamento cujos segredos a poética tem por objetivo desvendar. Definida como um sistema de desvios, a poesia aparece como pura negativi- 
dade, (des)construção da própria estrutura da linguagem. A poesia é uma linguagem sem negação, pois ela não tem um contrário de si mesma. O poeta tem por objetivo construir um mundo despacializado e destemporalizado, onde tudo será totalidade acabada. A poesia só conhece a necessidade e é por isso que ela é em que cada ser e cada coisa, liberta da sua negação, é entregue à sua própria identidade patética (COHEN, 1987, p. 249).

Cohen observa ainda que a lírica é autêntica fenomenologia, isto é, na e pela figuralidade poética é (des)vendado o sentido antropológico do universo habitado pelo homem, pois o mundo poético é o "mundo humano e a poesia é o discurso que o descreve na verdade [...] graças ao uso da linguagem patética, permite-nos - não pensar esse mundo, mas vê-lo e vivê-lo, de algum modo vê-lo viver” (1987, p. 157).

O poeta - como diz José Lezama Lima - por ser o "guardião da substância do inexistente como posibiliter" edifica uma poesia que é instante e descontinuidade (1996, p. 190). Na acepção de Lima, o poeta é o guardião das três grandes eficácias ou temeridades concebidas pelo homem: 1 . a conversão do inorgânico em vivente, da substância em espírito, pela penetração do alento do oficiante, ato nascente de transubstancialização, superação do ato nascente aristotélico em puro Nascimento; 2. O inexistente hipostasiado em substância; 3. A exigência total ganha pela superabundância na ressurreição (LIMA, 1996, p. 190). Tal plenitude frente ao "mundo da ressurreição" adquire domínios vastos, ou seja, o poeta, "ser causal para a ressurreição" faz da poesia uma potência pelo fato de o poema apresentar "o testemunho ou a imagem desse ser causal para a ressurreição, verificável quando o potens da poesia, a possibilidade de sua criação na finitude, atua sobre o contínuo das eras imaginárias" (LIMA, 1996, p. 221, grifo do autor).

Em meio à crescente "crise contemporânea da linguagem”, o escritor Italo Calvino, em Seis propostas para o próximo milênio (2000), identifica as seis qualidades que só a literatura tem o poder de salvar: leveza, rapidez, exatidão, visibilidade, multiplicidade e consistência, virtudes estas que balizam não apenas as atividades dos escritores em geral, mas também os gestos precisos da existência humana.

Calvino, ao se referir à palestra que ouvira na Itália, em 1963, retoma o pensamento de Giorgio de Santillana, sobre a conferência que esse autor ministrara e (re)lembra as informações sobre a precisão dos antigos egípcios ao observar os fenômenos celestes. Para eles, a precisão "era simbolizada por uma pluma que servia de peso num dos pratos da balança em que se pesavam as almas. Essa pluma levíssima tinha o nome de Maat, deusa da balança" (CALVINO, 2000, p. 71). Tal hieróglifo indicava ainda a unidade de comprimento e também o tom fundamental da flauta. 
Transpondo essa ideia para a contemporaneidade, Calvino salienta que as três coisas essenciais em relação ao tema da exatidão na literatura são: a) um projeto de obra muito bem definida e calculada; b) a evocação de imagens visuais claras, incisivas e memoráveis; c) e uma linguagem precisa no tocante ao "léxico e sua capacidade de traduzir as nuanças do pensamento e da imaginação" (CALVINO, 2000, p. 71-72).

Mediante imaginação poética e pensamento, o "artista da palavra", através das escolhas formais na composição, faz com que a obra literária seja "uma dessas mínimas porções nas quais o existente se cristaliza numa forma, adquire um sentido, que não é nem fixo, nem definido, nem enrijecido numa imobilidade mineral, mas tão vivo quanto um organismo" (CALVINO, 2000, p. 84). Por essa razão, a poesia é "filha do acaso", mas também "a grande inimiga do acaso", mesmo que este venha "em última instância" ganhar "a partida: Un coup de des jamais n'abolira le hasard" (MALLARMÉ apud CALVINO, 2000, p. 84, grifo do autor), afirma Calvino. Nessa perspectiva, a frase de Mallarmé e as observações precisas de Calvino em relação à poesia convergem para o universo da linguagem capaz de traduzir as nuanças do pensamento e da imaginação, sem esquecer o aspecto lúdico da linguagem, pois a poesia instaura uma espécie de jogo, em que o poeta e o leitor surgem como criadores. O primeiro decifra a Natureza e dá forma viva à linguagem; o segundo interpreta o momento de criação do poeta e completa o "circuito da poesia".

O filósofo Edgar Morin define a poesia como amor, estética, prazer, participação e, principalmente, vida (1998, p. 59). Ela é, igualmente, a manifestação de possibilidades infinitas da indeterminação humana. Já a criação poética tem o poder de reativar os conceitos analógicos e mágicos do mundo e, também, despertar as forças adormecidas do espírito, com o intuito de reencontrar os mitos esquecidos. Para o filósofo, a poesia não é somente um modo de "expressão literária", mas um "estado segundo" vivenciado pelo sujeito e que deriva da participação, da exaltação, embriaguez e, acima de tudo, "do amor, que contém em si todas as expressões desse estado segundo. A poesia é liberada do mito e da razão, mas contém em si sua união" (MORIN, 1998, p. 9). Essas duas forças são capazes de realizar a grande transformação vital, quer dizer, o amor se liga à "poesia da vida". Amor e poesia se mesclam e se identificam entre sí. Já o sentido do amor e da poesia aponta para a qualidade suprema da vida. Amor e poesia quando concebidos como fins e meios do viver - dão plenitude ao "viver por viver" (MORIN, 1998, p. 9-10). O filósofo ainda complementa: 
A vida é um tecido mesclado ou alternativo de prosa e poesia. Pode-se chamar de prosa as atividades práticas, técnicas e materiais que são necessárias à existência. Pode-se chamar de poesia aquilo que nos coloca num estado segundo: primeiramente, a poesia em si mesma, depois a música, a dança, o gozo e, é claro, o amor. (MORIN, 1998, p. $59-60)$

Em relação à figura do poeta, Morin destaca que este é portador de uma competência plena, "multidimensional", pois sua mensagem poética tem a capacidade de reanimar a "generalidade adormecida", ao mesmo tempo em que "reivindica uma harmonia profunda, nova, uma relação verdadeira entre o homem e o mundo" (MORIN, 1998, p. 158).

Wassily Kandinsky, em Ponto de linha sobre o plano, salienta que

[...] a criação ritmada do poema encontra sua expressão nas linhas retas e curvas, e sua alternância lógica se desenha com uma precisão gráfica na métrica poética. Fora das medidas ritmadas, que são precisas, o poema ganha com recitação de uma linha melódica musical, que exprime de maneira estável e variável o crescendo e o decrescendo, a tensão e a distensão. Essa linha é organicamente lógica, pois é ligada ao conteúdo literário do poema - tensão e distensão dependem do conteúdo (KANDINSKY, 2001, p. 89, grifos do autor).

A arte abstrata, no dizer de Kandinsky, deve contar com as formas mais precisas do que a arte figurativa, e que os problemas puramente formais são essenciais para a primeira, por vezes dispensáveis para a segunda. Examinamos a mesma diferença falando do ponto - e, como dissemos, o ponto é silêncio (2001, p. 89). Já a linha geométrica é um ser invisível, ou seja, é o rastro do ponto em movimento, logo seu produto, uma vez que ela "nasceu do movimento - e isso pela aniquilação da imobilidade suprema do ponto. Produz-se aqui o salto do estático para o dinâmico. A linha é, pois, o maior contraste do elemento originário da pintura, que é o ponto. $\mathrm{Na}$ verdade, a linha pode ser considerada um elemento secundário." (KANDINSKY, 2001, p. 49, grifos do autor).

Já o ponto geométrico, no dizer de Kandinsky, "é um ser invisível. Portanto, deve ser definido pelo imaterial. Do ponto de vista material, o ponto é igual a Zero" (2001, p. 17). O ponto geométrico é, nessa concepção do autor, esse Zero - o ponto geométrico - evoca a concisão absoluta, isto é, a maior reserva, que no entanto fala. Assim, o ponto geométrico é, de acordo com Kandisnky, a derradeira e única união do 
silêncio e da palavra. É por isso que o ponto geométrico encontrou sua forma material em primeiro lugar na escrita - ele pertence à linguagem e significa silêncio (2001, p. 17, grifos do autor).

Em relação ao desenho, Annateresa Fabris (2000), em Antonio Lizárraga: uma poética da racionalidade, destaca que ele tem merecido um destaque no âmbito da produção artística contemporânea. E salienta:

Se, até o século XX, o desenho fora um exercício, um ensaio que preparava e permitia testar a eficácia de um projeto que se materializava em outras técnicas, tal situação se modifica com as vanguardas históricas, que conferem autonomia ao que tinha sido visto até então como um meio auxiliar. Rompidas as antigas hierarquias que diferenciavam desenho e obra, projeto e objeto, o signo gráfico ganha um lugar privilegiado por favorecer a manifestação da rarefação da imagem interior. Não sendo constrangido pelo entrave da matéria, o desenho permite materializar diretamente o projeto da imaginação, pois flagra o momento que antecede o signo. Desse modo, evidencia que o momento de elaboração mental da obra começa antes de qualquer signo concreto, como sistema de relações espácio-temporais, como matéria desmaterializada à qual a folha de papel conferirá uma consistência bidimensional e, assim mesmo, impalpável (FABRIS, 2000, p. 103).

A autora observa ainda que o desenho tem o poder de "potencializar", fazendo aparecer a imagem através do movimento e, ao mesmo tempo, traduz o movimento direto da imagem em prol de uma execução rápida e direta (FABRIS, 2000, p. 104).

Nos desenhos de Lília A. Pereira da Silva, nota-se a intencionalidade da artista em organizar os espaços e as linhas do desenho, tal como em um jogo em que a emoção não está fora do tema, mas no plano da pura visualidade. Dessa maneira, ela dá visibilidade às linhas e formas a partir de uma operacionalidade em que o desenho adquire estruturas de signo construtivo, em que há a orientação da artista no sentido de dar expressividade às linhas, pontos, planos, cores, projetadas tanto no desenho quanto na pintura.

\section{Poesia, pintura e desenho em Lília A. Pereira da Silva}

Outra noite, ao fechar o livro, os olhos vermelhos de insônia, a cabeça fervendo de ideias em guerra, enquanto olhava sem olhar através da janela a paisagem negra, atravessada pelas luzes velozes 
dos automóveis, me ouvi a murmurar: cinzenta é a teoria, verde a árvore da vida. Verde ou dourada? Não importa.

Talvez verde e dourada. Octavio Paz (1991, p. 236)

Palavra poética e imaginação estão interligadas na lírica de Lília A. Pereira da Silva. Através da palavra e da leitura do poema ocorre o "circuito" da poesia.

No poema "Retrato" - de Lília A. Pereira da Silva -, a intensificação do amor à poesia e as imagens da estrela, floresta, ilha, flores, palhaços, trazem um encantamento lírico no enunciado do eu lírico:

\section{RETRATO}

Vivo ilha na floresta, cercada de gnomos, bruxas, e palhaços.

O caminho é só meu. A fome é minha, as flores exalam seiva do terreno venenoso.

Mas

uma estrela cadente

nunca deixou

de iluminar-me as mãos

nas Poesias.

(SILVA, Chuva de gatos verdes, 2004, p. 51). 


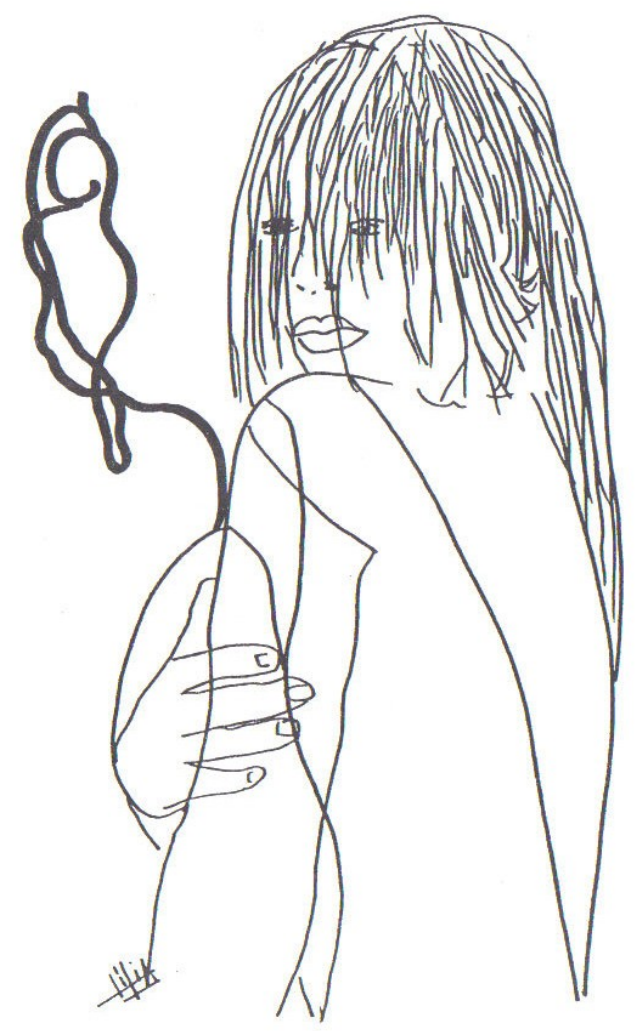

Figura 1: Desenho de Lília A. Pereira da Silva.

Fonte: SILVA, Desenhos para Pedrinho.

Percebe-se que a poesia liliana reside na busca memorável e densa das palavras e na concretização de um fazer poético enquanto "felicidade da expressão verbal", que no dizer de Calvino, efetiva-se mediante "uma fulguração repentina", em alguns casos, mas na maioria das vezes, tal processo implica sempre em "uma paciente procura do mot juste, da frase em que todos os elementos são insubstituíveis, do encontro de sons e conceitos que sejam os mais eficazes e densos de significado" (CALVINO, 2000, p. 61, grifos do autor). Dessa forma, o fazer poético liliano está embasado, essencialmente, na busca da palavra exata para concretizar a comunicabilidade lírica.

Na obra de Lília A. Pereira da Silva, as formas do imaginário não são simples temas. Elas ocorrem entrelaçadas quer às obras literárias quer às pictóricas no universo liliano, que registra imagens direcionadas a um cuidadoso processo de escritura e elaboração "poético-pictórica" alicerçados na imaginação poética, tal como no poema sintético: 


\section{RAZÃO MAIOR}

Mais que a vida, o mistério da Poesia.

(SILVA, Saia de cigana entre galáxias, 2001a, p. 105).

A construção poética e o projeto estético liliano residem nos procedimentos e nas formas escolhidas, nos ritmos, no enxugamento dos textos, "nas pinceladas poéticas" de palavras, cores e formas. Seus poemas registram o teor de modernidade e contemporaneidade. Assim, na poesia de Lília verifica-se a preocupação do eu poético em relação à elaboração precisa da linguagem, registrada na maneira de interpretar o mundo e as coisas.

No poema "Serva da poesia", as indagações da linguagem e os questionamentos do eu lírico direcionam o poema para um sentido de busca da expressão poética e de comprometimento com a poesia:

\section{SERVA DA POESIA}

De quem é o palhaço sobre a mesa e o rei que na lonjura me seduz? Arredem esta máscara em meu quarto: no quotidiano quero ser sem ela.

Por que me procuram os maltrapilhos inatos do saber e da bondade, se o que procuro é ser como queria curtindo a solidão, mais fiel serva, à fonte dos versos que fui eleita?

(SILVA, Chuva de gatos verdes, 2004, p. 83). 


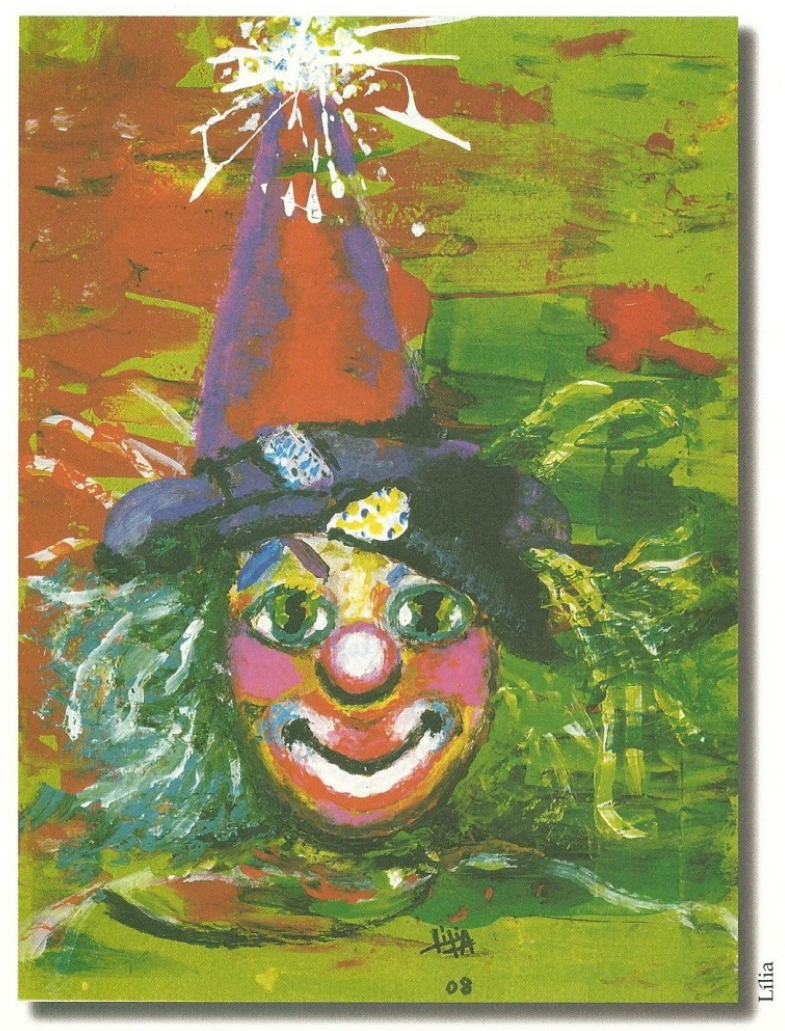

Figura 2: "Palhaço Chicão e Me-Acuda".

Fonte: SILVA, Histórias o espantalho pescador, 2010, p. 45.

Do ofício do verso à procura constate da poesia, o eu lírico afirma "curtir a solidão", que se presentifica na maneira de o poeta sentir o mundo na entrega completa do ato criador, enquanto exercício e comprometimento perante a vida e a arte, mediante a efetivação de um pensamento capaz de (re)inventar universos imaginários.

A forma como o sujeito da enunciação se projeta, sem máscaras, faz do poeta um apaixonado pela linguagem ao compartilhar a palavra com o interlocutor, ou seja, mediante a palavra e encantamento da linguagem, a poesia liliana torna-se expressão máxima de uma constante mediação fraterna, centralizada no diálogo e comunhão. 


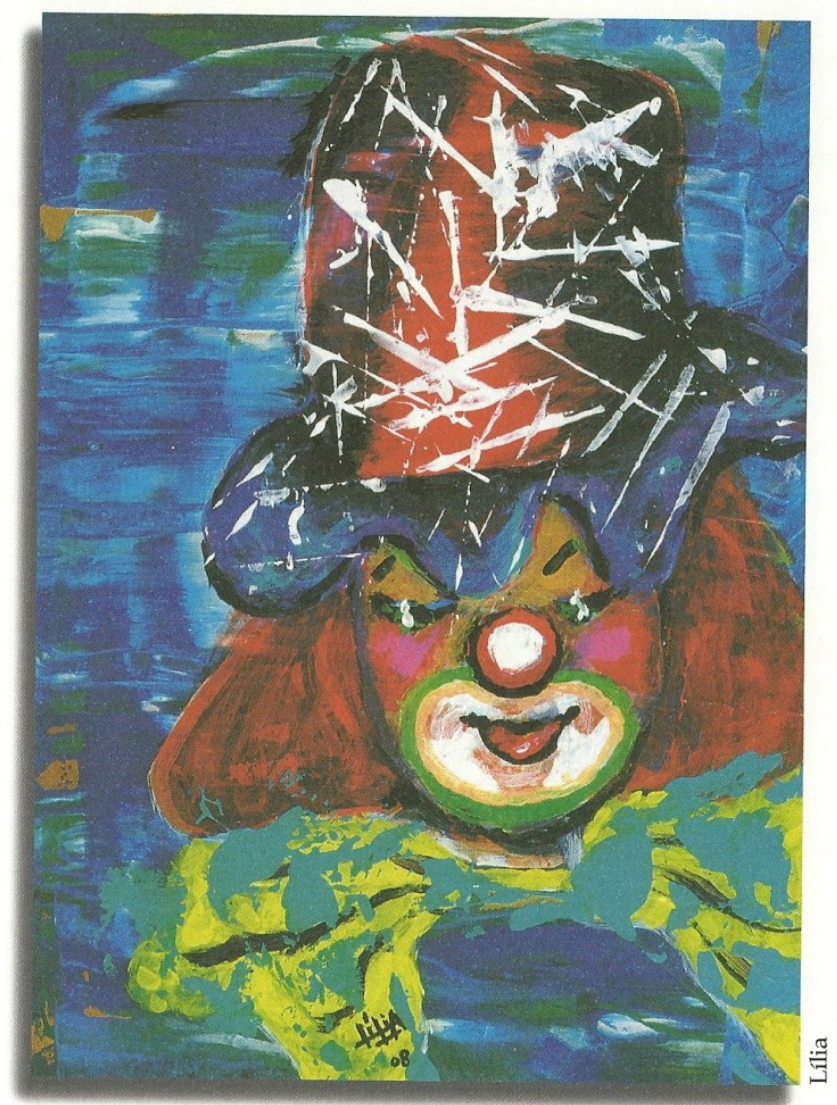

Figura 3: "Palhaço 'Plim Plim"”...

Fonte: SILVA, Histórias o espantalho pescador, 2010, p. 118.

O poema intitulado "O Palhaço" mostra a magia de um tempo e espaço exuberantes, marcados pela distração do eu lírico no tempo da infância, das representações circenses e da fantasia envolvente, que encontra no tempo passado, uma forma do sujeito de enunciação (re)memorar situações vivenciadas mediante a palavra poética: 


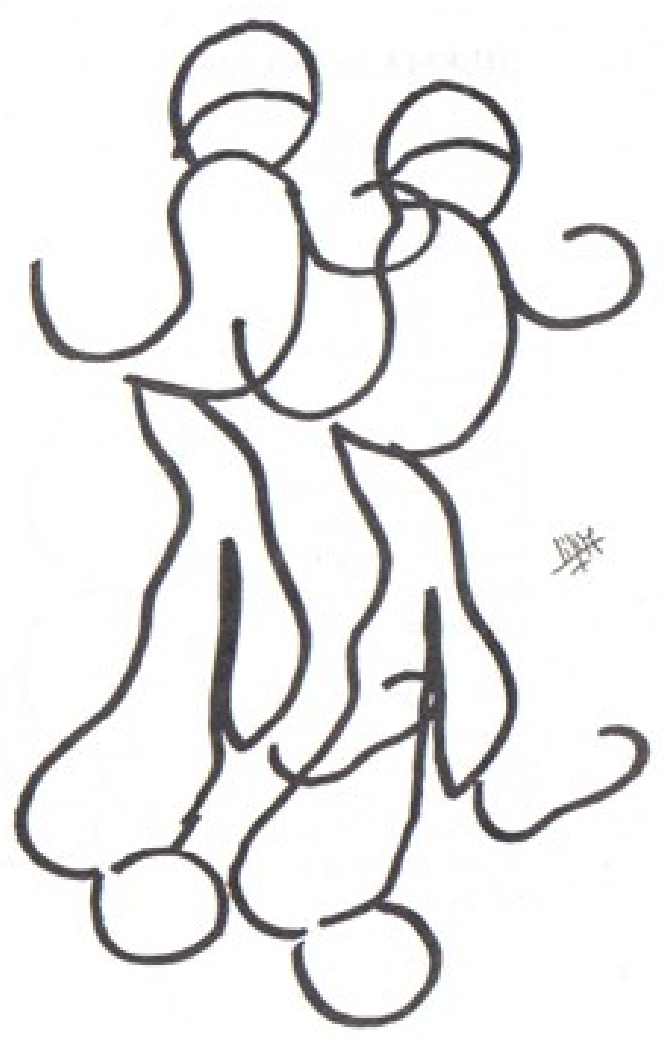

Figura 4: Desenho de Lília A. Pereira da Silva.

Fonte: SILVA, Impacto, 1996, p. 60.

\section{O PALHAÇO}

Não conhecia os deuses em criança.

Eles é queme sabiam

ditando-me poesias.

No circo, o palhaço era todosdeuses

que eu conheceria.

Na juventude, virouestátua

colorida

- o sorridente mágico a brincarcomigo

e a invadir-me telas e pincéis.

Hoje é obelisco, nos meus cabelos brancos, mais alto que o cume de outrastorres.

Tão mágico, tão insistente que é o único

a invadir-me as venezianas

sorrindo, nas alvoradas,

a deitar notravesseiro que o espera.

São Paulo, fevereiro de 1995.

(SILVA, Impacto, 1996, p. 61). 
Mediante o ato imaginativo, Lília A. Pereira da Silva concretiza uma poesia que é mediação solidária com o leitor, ou seja, sua voz "participativa" abre múltiplos espaços de interlocução. O desenho de palhaços - da artista e poeta Lília A. Pereira da Silva - que ilustram o poema, com seus traços e linhas envolventes, em redobramentos, se destacam na interação desenho/palavras, registrando a proximidade temática da figura dos palhaços com os versos que apresentam imagens do tempo e de vivências do eu lírico, que se diz envolvido pela magia das cores e das formas representativas dos palhaços. $\mathrm{Na}$ infância e adolescência, eles eram os portadores da alegria e futuros "deuses". Esses mesmos palhaços que se presentificaram nas "telas" coloridas, dão significado à vida do eu lírico, no tempo presente, projetando momentos de alegria, com seus sorrisos a invadir o espaço vital do sujeito lírico. A poeta Lília elabora novos procedimentos com os versos do poema efetivando a junção de duas ou mais palavras, criando, assim, imagens inusitadas.

A síntese é, também, forma escolhida intencionalmente pela Poeta, com seus versos precisos, sugestivos, com imagens visuais nítidas, com suas "pinceladas" de palavras-cores, com uma poesia marcada pela exatidão e que projeta espaços de interação eu-leitor-mundo, concretizando, dessa maneira, uma operação poética que registra uma linguagem que traduz as nuanças do pensamento e de uma imaginação lírica, consubstanciada naquilo que Calvino, referindo-se às definições de imaginação a partir do pensamento de Starobinski, denomina "descrição minuciosa do mundo" capaz de exprimir "o segredo da vida". Assim, a imaginação do artista - espécie de "máquina eletrônica" revela-se como "um mundo de potencialidades", isto é, "a mente do poeta, bem como o espírito do cientista em certos momentos decisivos, funciona segundo um processo de associações de imagens que é o sistema mais rápido de ordenar e escolher entre as formas infinitas do possível e do impossível" (CALVINO, 2000, p. 107). Dessa forma, mediante os artifícios da linguagem e a (inter)ligação poesia e imaginação, configuram-se, nos versos lilianos, uma (re)evocação através da palavra instauradora de sentidos, projetando, assim, um espaço mágico e de encantamento perante o ofício do verso. 


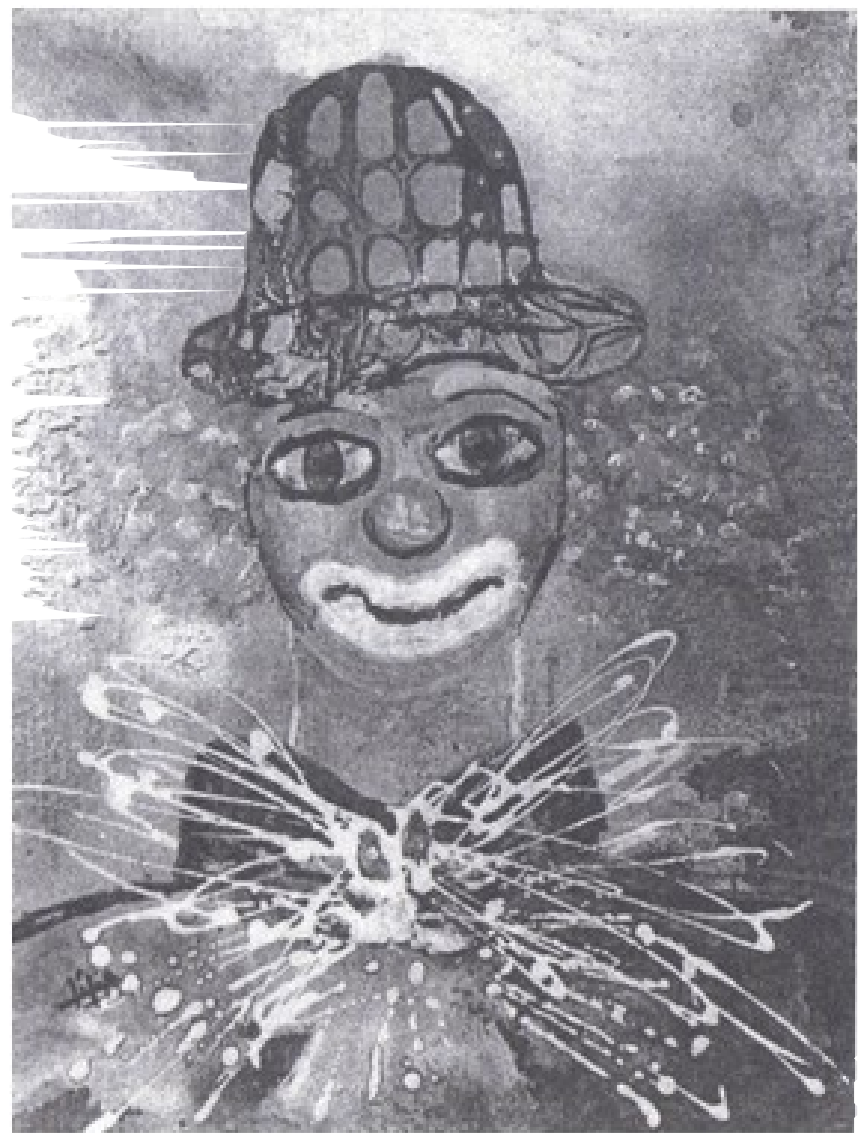

Figura 5: Imagem da pintura da série "Palhaços", em papel com téc. mista,

São Paulo, 1991, de Lília A. Pereira da Silva.

Fonte: SILVA, Desenho e Pintura, 2002, p. 321.

"Cair da estrela" é um texto que relaciona a imagem do poeta como "vidente" capaz de ver os "fantasmas coloridos", de discernir as vicissitudes da vida:

\section{CAIR DA ESTRELA}

Estrela caiu na calçada.

Dá risada o palhaço,

e passa.

O mudo maravilhado angustia-se da beleza, e guarda-a.

O cego, não a pressente e talvez a sonhe.

O fauno abraça-a.

Éolo, fá-la brilhar mais que outras, 
mas é arauto indiferente.

Ninfas comentam a estrela

Ser poeira da lua, ainda,

depois, nada.

Mas o poeta namora o pedestal

sangrado, sob a estrela.

Vê fantasmas coloridos

que volteiam o astro.

E, cocheiro de sua alma,

ouve-a relógio de relâmpagos,

mesmo assim caída,

e deslumbra-se dela.

É o único que sabe

que ela trocou o azul

e seu corpo,

por rosas.

(SILVA, Altar das cicatrizes, 1966).

Os versos são livres, cadenciados por um ritmo que decorre da sucessão dos grupos de força valorizados pela entonação, pela maior ou menor rapidez na enunciação. Na base da criação poética liliana estão a noção de ritmo e o senso de trabalho poético. Ao assumir o verso livre, o Eu poético reflete sobre o que pode haver de efetivamente poético no que se refere à arte de criação. Ao se valer da linguagem metafórica, o sujeito poético encontra inusitadas formas de sentido ao seu ato criador. 


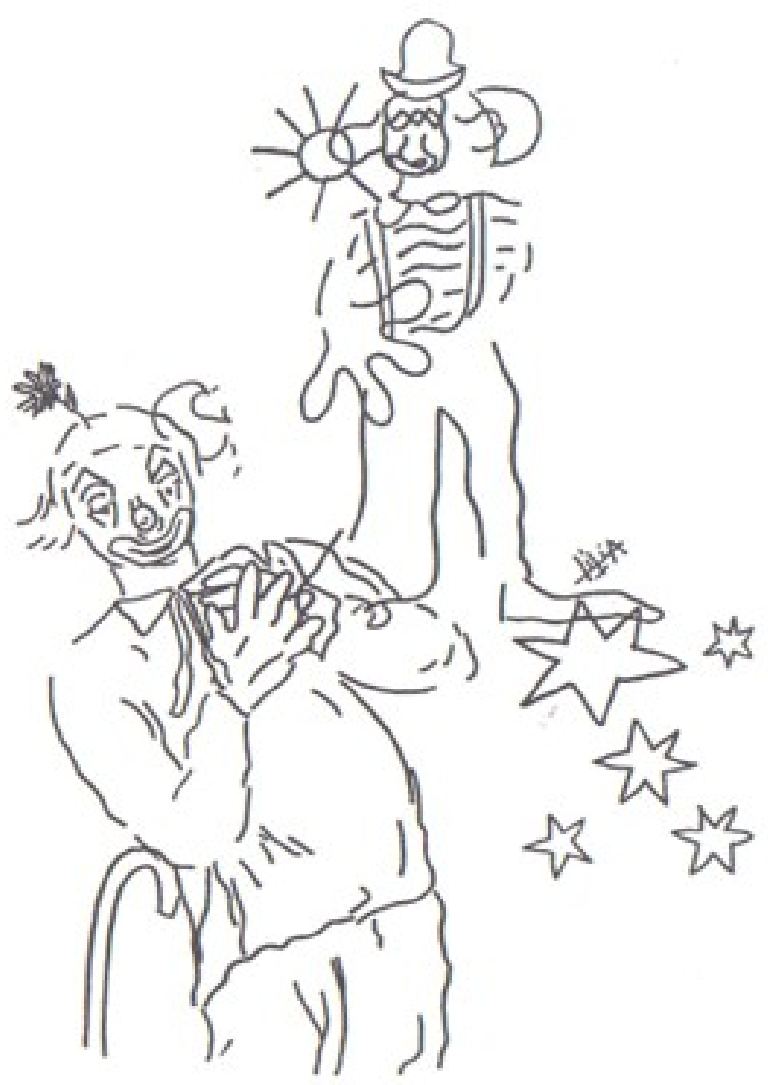

Figura 6: Desenho de Lília A. Pereira da Silva Fonte: SILVA, Desenhos para Pedrinho.

Sobressai, nos versos, a imagem do poeta enquanto "vidente" capaz de ver e sentir as manifestações da vida com suas estrelas matizadas de luzes, cores e poeiras que representam espaços de poesia-vida.

As imagens do poema como "lua", "estrela", "astro", são comparadas como aqueles objetos intencionais de que fala Roman Ingarden, para que algo de diferente aconteça, pois, o estrato dos objetos apresentados na obra de arte tem a função de trazer à luz determinadas qualidades metafísicas, e ao mesmo tempo, revelá-las. É por essa razão que ele vê a obra de arte como um milagre, ou seja, ela "existe e atua sobre nós e enriquece extraordinariamente a nossa vida, oferece-nos momentos de deleite e de descida às profundezas abissais do ser" (INGARDEN, 1979, p. 409).

"Chão dividido" apresenta-se como uma poesia participativa, em que o eu lírico feminino busca dividir suas alegrias, seus momentos mágicos, quer na "alegria de viver" 
quer nos sentimentos de solidão, nas cintilações das estrelas, na forma de lírios ou abismos, mas, acima de tudo, enquanto "sinal de dividir":

\section{CHÃO DIVIDIDO}

Dentro de minhas paredes, sinal de dividir.

Em meu traje de freira, sinal de dividir.

No vestido de palhaça, sinal de dividir.

Nos andrajos de mendiga, meu sinal de dividir. Em meu gesto de ladra, sinal de dividir.

Em meu casaco de fera, sinal de dividir.

$\mathrm{Na}$ fantasia de mãe, meu sinal de dividir.

Na solidão, na estrela, no lírio do meu passado, no abismo de mornas noites, no vento lambendo estigmas na coroa de minha fronte, o sinal de dividir!...

Minha prisão: só a minha, sinal-sempre: dividir! Os pulsos, se dou a faunos, e juro fidelidade, prometo, se há silêncio, prometo, se há palavra, prometo ao corpo e ao espírito, prometo a mim dividir-me. (SILVA, Altar das cicatrizes).

São versos que mostram o poder da palavra poética e a força da linguagem na confluência participativa do sujeito lírico/leitor, com suas nuanças frente aos sinais de partilha e comunicabilidade lírica que a poesia é capaz de proporcionar. $\mathrm{O}$ eu lírico feminino, ao vivenciar a condição de solidão, faz do "chão dividido" - metáfora de vida - um espaço aberto de partilha para com o outro, sempre direcionando o sentido da vida ao "sinal de dividir", quer seja com seus trajes de freira, de palhaça, nos andrajos de mendiga, ou "na fantasia de mãe". Nos espaços mais aconchegantes, íntimos, de vivências solitárias, há os momentos de uma participação efetiva do eu lírico no "sinal- 
sempre" de dividir e na entrega de "corpo e espírito" à fidelidade e promessas da palavra e do silêncio.

A poesia liliana aponta para a experiência cotidiana e a transcende mediante a imagem poética, que se reporta a uma dimensão maior, despertando no leitor um sentimento de plenitude e fascinação perante as palavras. Assim, a poesia é uma forma de auto-revelação, que permite um constante "recriar-se e recriar-nos", pois conforme Octavio Paz, ela "é um tecido de conotações, feita de ecos, reflexos e correspondências entre som e sentido" (1991, p. 151). Na obra de Lília A. Pereira da Silva há todo um universo de recordações que direcionam para lugares e espaços vitais. Mediante a linguagem poética - enquanto viagem e travessia - a Poeta rememora impressões de viagens e recupera fatos e momentos vividos no exercício poético e imaginário.

No poema "O traje", o eu lírico expressa sua condição existencial:

O TRAJE

porque na pupila existencial e na morta

a noite foi sempre espinho,

os palhaços sentaram-se na soleira da memória

e me emprestaram as vestes.

então me inebriei da canção de arena

de tua sombra,

e irresponsável e encorajada,

aguardei o resultado da espera.

(SILVA, Estrela descalça. p. 19). 


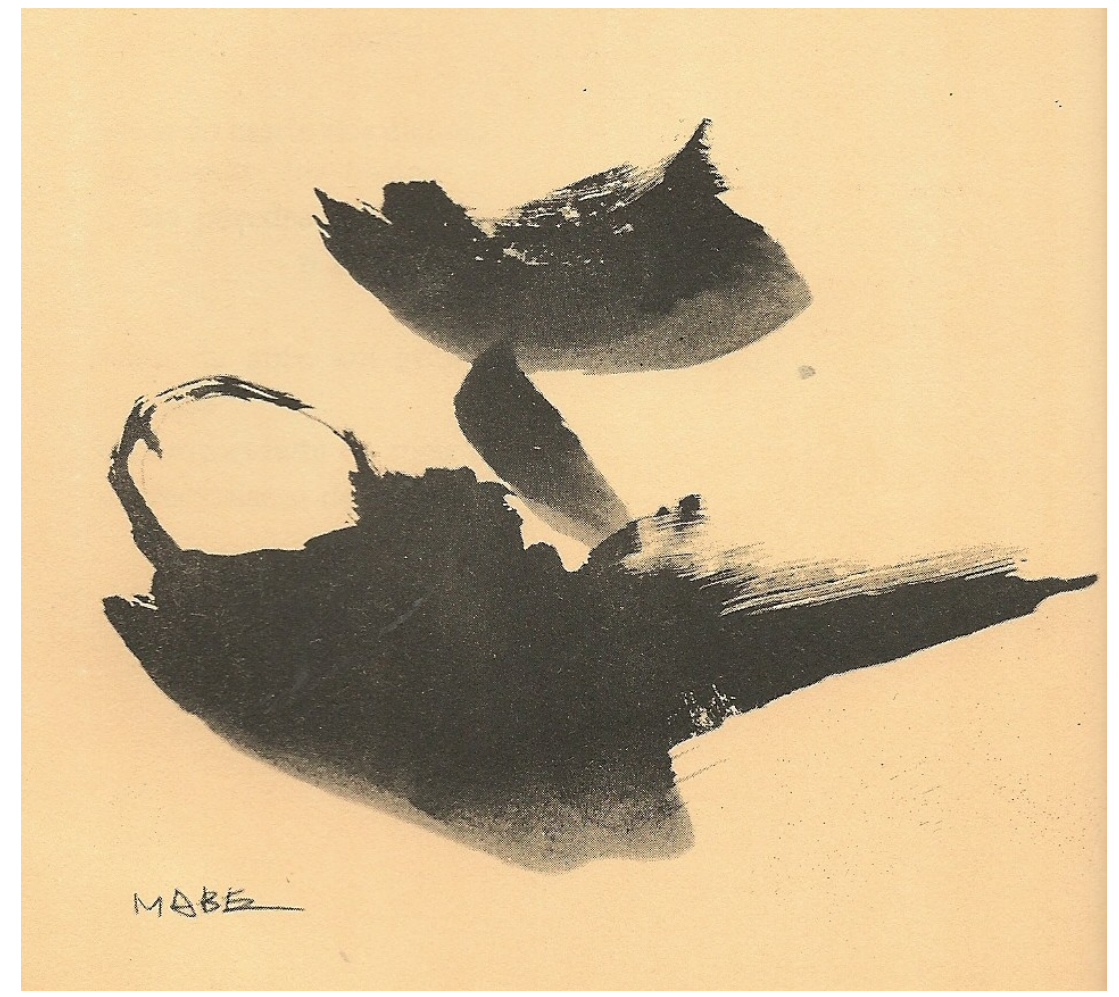

Figura 7: Ilustração de Manabu Mabe.

Fonte: SILVA, Estrela descalça, p. 19.

"Do Poema" é um texto que apresenta imagens relacionadas ao ofício poético, no qual a poesia é vista como destino pelo eu lírico, ou seja, "um vício" marcado pela forma "mais útil", entre abismo de encantamento do eu para com a linguagem do poema:

\section{DO POEMA}

Corvos presos em redomas, galos que acordam no ocaso, anjos de estercos e chifres, deuses marcados de andrajos, são o meu vício mais útil, no abismo roxo, encantados.

são o meu vício mais útil, no abismo, tão abraçados. na sola, em borrões azuis se esborrifam no futuro quando retorno o meu passo.

são o meu vício mais útil, 
e nos meus nervos, fadados.

(SILVA, Estrela descalça. p. 26).

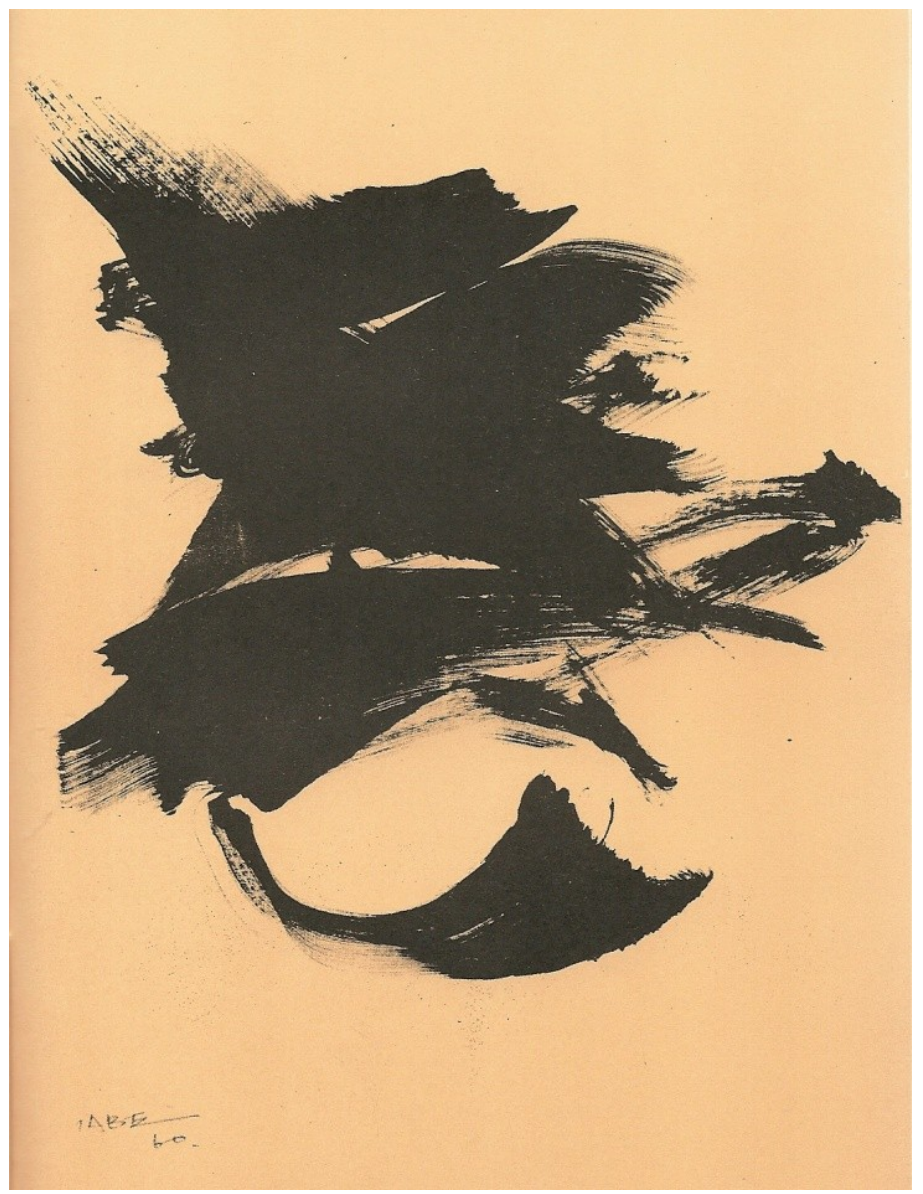

Figura 8: Ilustração de Manabu Mabe.

Fonte: SILVA, Estrela descalça, p. 26.

O texto é um convite ao leitor para partilhar do processo poético e é um presente original e comunicativo do eu poético ao leitor. Além de comunicação, a poesia é participação e revelação do ser. Nesse sentido, Iuri Lotman (1978), afirma que a representação da criação poética tem como base os modelos cibernéticos do processo criador, ou seja, a escolha das variantes possíveis da formulação de um determinado conteúdo deve levar em conta as regras formais restritas. Se para o criador do texto se esgota a entropia da flexibilidade da linguagem, para o receptor pode ser de um modo muito diferente. O poeta sabe que podia ter escrito de outro modo. Para o leitor, não há nada de contingente no texto, recebido como artisticamente perfeito. O poeta é auditor 
dos seus versos e pode escrevê-los guiado por uma consciência de auditor. Dessa forma, a flexibilidade da linguagem passa a uma carga significativa complementar, elaborando uma entropia particular do conteúdo poético. A simples repetição de uma palavra várias vezes torna-a desigual a ela própria (LOTMAN, 1978, p. 66-67). Nesse sentido, a explícita reiteração pelo sujeito da enunciação nos versos: "são o meu vício mais útil", apresenta um jogo de imagens interligadas ao ofício poético e à consciência do Ser. A imagem do "abismo, roxo, encantados" e "os borrões azuis", com suas perspectivas do futuro, faz com o que o poeta trilhe os caminhos de partilha da poesia e, nesse embate, se sente com seus nervos "fadados" perante o mistério de encantamento do Eu para com a palavra poética, ou seja, um espaço de participação, pois o poema, com suas imagens dos "corvos", "galos", "anjos" e "deuses", configura um sentido vital à arte, concretizando, assim, a "heterogeneidade do ser", de que fala Paz. Desse modo, o texto "Do poema" tematiza o fazer poético, evidenciando a relação poesia/linguagem, pois a linguagem é "poesia em estado natural”, no dizer de Paz. Em sua essência a linguagem é simbólica, ou seja, consiste em representar um elemento da realidade por outro, tal como ocorre com as metáforas. Cada palavra ou grupo de palavras é uma metáfora. A palavra é símbolo que emite símbolos (PAZ, 1982, p. 41).

A ilustração do poema, realizada pelo Artista Manabu Mabe, traz imagensdesenho que parecem formas de pássaros - corvos, galos, seres voláteis - aproximando, assim, as pinceladas que apontam para um processo criativo e imaginário dando a ideia de leveza, mesmo que no dizer do eu lírico, os corvos estejam "presos em redomas". A imagem do corvo relacionada ao ofício da poesia é uma constante na literatura mundial, a exemplo do poema "O corvo", de Edgar Alan Poe. A imagem do corvo, no dizer de Chevalier e Gheerbrant, está, muitas vezes, relacionada ao processo criativo e à inteligência, isto é, a imagem desse pássaro negro é representada pela intersecção entre o plano divino e o humano (2002, p. 690). Conforme os autores, a imagem do pássaro, das aves em geral - na poesia - pode estar também relacionada ao canto da criação poética, naquilo que Saint-John Perse apresenta de forma intuitiva uma "espécie de pureza primordial nesta linguagem [dos pássaros], quando escreve: Os pássaros guardam entre nós alguma coisa do canto da criação" (PERSE apud CHEVALIER; GHEERBRANT, 2002, p. 690; grifos dos autores).

Em "Poema da posse", as imagens de pássaros, papoulas, faunos, rosas, ninfas, sóis, estão relacionadas ao ofício do verso, no qual o sujeito da enunciação busca no tempo presente, no "agora", o olhar de concentração à natureza circundante: 
POEMA DA POSSE

Agora,

além da janela

serão gestos de linho,

pássaros chineses e papoulas.

repousarão luares de neblinas

e sóis de ramos cinzentos.

o chão será de paina e carneiros,

e os chacais, perdidos na distância.

agora,

os pássaros chineses e papoulas

encantarão os faunos que desamei

e as ninfas que te formaram,

em rosas de pó,

florindo outubros...

(SILVA, Estrela descalça, p. 42).

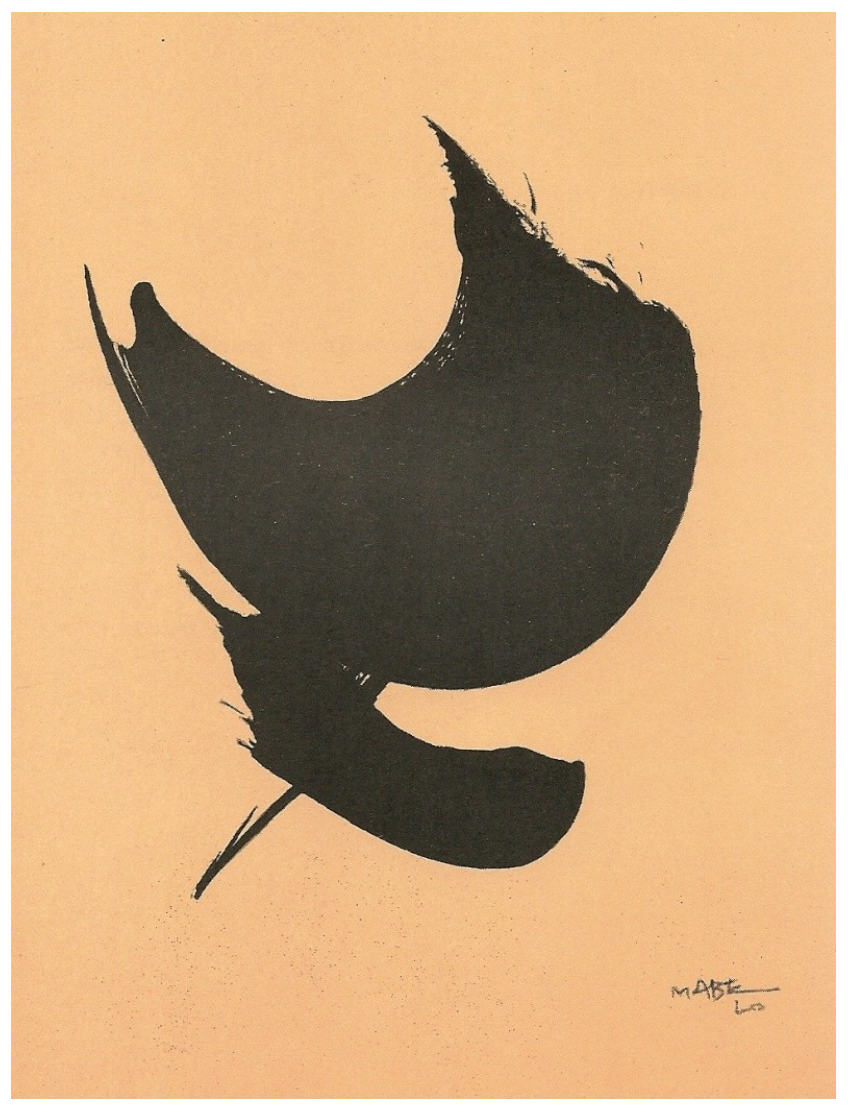

Figura 9: Ilustração de Manabu Mabe.

Fonte: SILVA, Estrela descalça, p. 42. 
A palavra "pássaro" pode simbolizar o poema ou a palavra poética, cuja associação imagética justifica-se na medida em que o pássaro e outros seres alados são símbolos de espiritualização. A imagem do pássaro simboliza, ainda, a manifestação do plano espiritual. O poder de voar predispõe o pássaro a ser símbolo de transcendência. Segundo Chevalier e Gheerbrant, o pássaro simboliza, na poesia, a imortalidade. Simboliza ainda a alma, e tem um papel de intermediário entre a terra e o céu (2002, p. 687-690). Já a ilustração do poema - por Manabu Mabe - dá a ideia-imagem de um pássaro, pois o Artista, com pinceladas rápidas, desenha a forma de um pássaro. Segundo Chevalier e Gheerbrant, os pássaros simbolizam, também, "os estados espirituais, os anjos, os estados superiores do ser. Os numerosos pássaros azuis (Maeterlinck) da literatura chinesa dos Hans são fadas, imortais, mensageiros celestes" (2002, p. 687, grifos dos autores).

Em "Poema rubro", nota-se, por parte do eu lírico, que o fazer poético é capaz de atingir pontos culminantes de uma busca que se faz anseios; de sentir que os "cacos da ilusão", ficam em segundo plano frente à forma de ver a vida enquanto fonte de “infinito", uma vez que a escrita do poema surge como sinal de permanência:

\section{POEMA RUBRO}

ferido, cabisbaixo, já não existes com cacos de ilusão dentro do bolso. e já não escrevo apenas, no infinito o meu anseio, com o giz das estrelas,

agora, nascidos colunas sobre o abismo, e tocados de sol, com nossas máscaras pendentes. (SILVA, Estrela descalça, p. 43).

Os versos evidenciam que, mediante a força da palavra poética e com "o giz das estrelas", é possível (re)configurar os desenhos de tempo presente, situados no "agora", mesmo que haja o abismo e as "máscaras pendentes", a imagem do sol sobressai enquanto fonte de luz e energia portadora de um sentido vital.

"Façanha do apuro", de número um, apresenta imagens do tempo relacionadas à poesia, definida como escudo capaz de proteger o eu lírico das adversidades da vida: 
Façanha do apuro

a vida, até agora.

Pecado inacabado,

Até amanhã.

Muletas na alma,

usadas

na distorção da cartola do mágico,

que me cobre a nudez

com margaridas de espadas.

Que as patas do trovão

voltem eternas;

cavalgarei em mim

- poesia-escudo.

(SILVA, Pólen de Faunos (Cartas de Amor), 1991, 33 anos de Poesia, vol. 1, p. 11).

Qual um "mágico", o eu poético faz com que sua poesia se desdobre verso a verso, imprimindo a cada série verbal, a busca de uma unidade totalizadora do espaço que logo é retomada pela consciência da fragilidade do tempo. Nesse sentido, o tempo presente surge da tomada física do espaço, com o qual o sujeito poético reinventa um mundo de sentidos. O poema ganha, assim, contornos de uma linguagem que vai ao encontro do processo de objetivação e substantivação, sendo o poema o próprio objeto. Já o poeta - mágico da linguagem - entre as "façanhas do apuro" e no "agora" do viver, faz da "poesia-escudo" uma forma de eternizar o instante poético.

Em “Anjo Narciso", realidade e imaginação se configuram no poema formando uma rede de imagens:

\author{
ANJO NARCISO \\ Preferir o anjo \\ não era fantasia: \\ eu estava nua \\ e precisava tatuar-me \\ da galáxia, \\ sem mais permitir \\ me consumirem \\ cintilâncias. \\ E o recebi com hálito de harpas, \\ confuso de gardênias e jasmins \\ e promessas de sonhos nem pensados. \\ E o recebi. Mas ele não me olhava \\ - $o$ anjo leve qual plumas de estrelas...
}

Eu escolhera o anjo alentador de risos, 
de coração de sol e lua pelos dedos, mandala de gaivotas pelos passos, Mas ele persistiu tão só se olhando e não se deu a mim sequer de esmola, e não ouviu o rumor do meu grito,

a que eu entendesse, descalça de fascínios, ser toda preferência, fantasia.

(SILVA, Elipses do Anjo, 1993, p. 17).

$\mathrm{O}$ ato criador liliano reveste-se de uma sistemática arquitetura, operação alquímica com as palavras, com uma poesia que se centraliza nos artifícios da construção poética e na "lapidação" da matéria verbal, com uma imagística que visa transcender a expressão comum. Nos versos do poema, o eu lírico feminino se diz nua, ao preferir o "Anjo Narciso", com suas "promessas de sonhos" e "hálito de harpas". Há, no texto, a acolhida por parte de eu lírico, mas o mesmo não ocorre com o anjo que não corresponde aos anseios de sujeito lírico pela forma de "ser toda preferência" e de sobrepor a fantasia à realidade. Na busca do outro, enquanto "anjo leve qual plumas de estrelas", o eu lírico sente a carência e necessidade de tatuar-se da galáxia e suas cintilações.

Nos versos do poema constata-se a capacidade criadora da poeta Lília ao dar sentido ao seu ato criativo, pois ao elaborar o texto, independentemente de ser um mero reflexo do mundo exterior ou uma criação do cérebro, ou do sentimento humano, ela o alicerça tendo por base a imaginação criadora, baseando-se na combinação, de dar um sentido distinto à criação literária.

Verifica-se na poesia de Lília A. Pereira da Silva, uma articulação laboriosa em relação ao fazer poético, o cuidado na escolha do vocábulo, pois a Poeta coordena o maior número de partes e de fatores independentes na elaboração do poema, como o som, o sentido, a sintaxe, o real e o imaginário, a lógica e também a dupla invenção do conteúdo e da forma. Através da linguagem cotidiana, comum, a poeta Lília Silva arquiteta uma construção lírica que apresenta "uma Voz pura, ideal", - como diz Valéry - "capaz de comunicar sem fraquezas, sem aparente esforço, sem atentado ao ouvido e sem romper a esfera instantânea do universo poético, uma ideia de algum eu maravilhosamente superior" (VALÉRY, 1991, p. 218, grifo do autor).

Na obra de Lília A. Pereira da Silva, as imagens poéticas ocorrem entrelaçadas no universo imaginário, que registra imagens-desenhos-pinturas alicerçadas nos "registros-chave", que direcionam para um elaborado processo poético-criativo centrado 
na imaginação poética e na ARTE. Assim, constata-se, na poesia liliana, a efetiva preocupação do Eu poético em relação à elaboração precisa da linguagem, registrada na forma de interpretar e vivenciar o mundo e as coisas, isto é, ao "celebrar" a poesia, Lília Silva apresenta o ato criador como um exercício de encantamento da linguagem e comprometimento perante a vida e a arte.

\section{REFERÊNCIAS}

Obras de Lília A. Pereira da Silva

SILVA, L. A. P. da. Estrela descalça. Capa e ilustração de Manabu Mabe. São Paulo: 1960 (Coleção dos Novíssimos).

. Serenata do abismo. São Paulo: Alarico, 1963.

. Altar das cicatrizes. São Paulo: Brasil, 1966.

Pólen de Faunos (Cartas de Amor). In: 33 anos de Poesia, 1991, vol. 1.

33 anos de poesia. São Paulo: Scortecci, 1991 (vol. 1).

33 anos de poesia. São Paulo: Scortecci, 1991 (vol. 2).

Elipses do anjo. São Paulo: Scortecci, 1993.

. Impacto. São Paulo: Scortecci, 1996.

. Carnaval Brasil / Carnival Sketches. São Paulo: Scortecci, 1996.

Europeanas. São Paulo: Scortecci, 1997a.

. Carta à minha sombra. São Paulo: Scortecci, 1997 b.

. Saia de cigana entre galáxias. São Paulo: Scortecci, 2001a.

Desenhos para Pedrinho. São Paulo: Scortecci, 2001b.

. Desenho e pintura / Lília A. Pereira da Silva. São Paulo: Scortecci, 2002.

. Chuva de gatos verdes. São Paulo: RG Editores, 2004.

. Diário na Suíça. São Paulo: RG Editores, 2005.

História do espantalho pescador. São Paulo: RG Editores, 2010.

Obras teóricas

CALVINO, I. Seis propostas para o próximo milênio. Trad. Ivo Barroso. São Paulo: Companhia das Letras, 2000.

CHEVAlIER, J.; GHEERBRANT, A. Dicionário de símbolos. Rio de Janeiro: J. Olympio, 2002.

COHEN, J. A plenitude da linguagem (Teoria da poeticidade). Coimbra: Almedina, 1987.

FABRIS, A. Antonio Lizárraga. Uma poética da radicalidade. Belo Horizonte: C/ Arte, 2000. 
INGARDEN, R. A obra de arte literária. Lisboa: Fundação Calouste Gulbenkian, 1979.

KANDINSKY, W. Ponto e linha sobre o plano. São Paulo: Martins Fontes, 2001.

LEZAMA LIMA, J. A dignidade da poesia. Trad. Josely Vianna Baptista. São Paulo: Ática, 1996.

LOTMAN, I. A estrutura do texto artístico. Lisboa: Estampa, 1978.

MORIN, E. Amor, poesia, sabedoria. Trad. Edgard de Assis Carvalho. Rio de Janeiro: Bertrand Brasil, 1998.

PAZ, O. O arco e a lira. Trad. Olga Savary. Rio de Janeiro: Nova Fronteira, 1982 (Coleção Logos).

Convergências: ensaios sobre arte e literatura. Trad. Moacir Werneck de Castro. Rio de Janeiro: Rocco, 1991.

VALÉRY, P. Variedades. São Paulo: Iluminuras, 1991.

Artigo recebido em 12/09/2012

Aceito para publicação em 24/09/2012 